\title{
Media, Ranah dan Dinamika Permainan
}

\author{
Amirudin \\ Program Studi Antropologi, Fakultas Ilmu Budaya \\ Universitas Diponegoro \\ Email: amdjtg@yahoo.com
}

\begin{abstract}
In the 21 st century, the media is increasing rapidly and requires a specific response from anthropology studies. Not only does the media bring with implications for changes in the process of production and consumption of culture, but also changes to its viewpoint and approach. It's not enough if the media was studied only with a classical perspective that only positioned the media as a cultural communication agent, or otherwise the media is approached with the effects study. However, the media also needs to be recognized with a more progressive perspective that positions the media as an agency in cultural production practices. Based on the idea, this paper provides provocation through Amirudin's research (2016) which tried to present a new perspective in media studies.
\end{abstract}

Keyword: Media, Anti-esensialist Study, Field

\section{Pendahuluan}

Di abad ke-21 ini, seirama dengan makin berkembangnya pemanfaatan teknologi media, maka studi mediapun bergeser dari studi efek ke studi-studi produksi media. Begitupun di studi antroppologi mulai beringsut pula menggeser orientasi studinya dari sekadar studi esensialis ke studi yang anti-esensialis yang memposisikan media bukan saja sebagai objektifikasi kepentingan ekonomi politik, tetapi juga sebagai agensi yang memrproduksi kebudayaan.

Bagi Mazzarella (2004), produksi dan reproduksi kebudayaan merupakan suatu proses yang melibatkan keseluruhan domain kehidupan masyarakat. Media hanya salah satunya. Tentu saja derajat peran media dalam proses produksi kebudayaan di suatu masyarakat bervariasi, akan tetapi, seiring perkembangan teknologi informasi dan komunikasi, masyarakat kontemporer semakin sulit untuk luput dari keterhubungan media dalam proses interaksi sosialnya. Dalam situasi tersebut, akan sulit membantah bahwa media memiliki peran yang makin signifikan dalam proses produksi budaya di suatu masyarakat. Kekuatan ekonomi dan politik global, nasional dan lokal saling terhubung melalui media dalam proses produksi budaya tersebut. Kekuatan-kekuatan ini tentu tidak simetris, dan pada tingkat tertentu, terdapat aktor yang jauh lebih dominan dibanding aktor lainnya. Ketidaksimetrisan kekuatan tersebut, bagi sebagian sarjana, membawa konsekuensi yang sepadan terhadap dominasi peran pembentukan kebudayaan, setidaknya kebudayaan yang ditampilkan melalui produk media. Terdapat asumsi kekuatan ekonomi-politik pararel dengan dominasi proses budaya (Adorno, 1991).

Melalui studi Amirudin (2016) berjudul "Tayangan Religi sebagai Ranah Produksi Budaya: Kajian terhadap Tayangan Mamah dan Aa Beraksi di Stasiun TV Indosiar", menunjukkan baghwa asumsi tersebut gagal melihat dinamika proses penciptaan produk media. Didasarkan pada pengamatan etnografis dari dekat, studi ini memperlihatkan bahwa kekuatan dominan yang menguasai media tak serta merta tampil 
sebagai aktor dominan dalam proses produksi kebudayaan. Dengan melihat produksi tayangan sebagai wujud mikro dari proses produksi kebudayaan pada lingkup lebih luas, tampak bahwa diversitas aktor yang terjalin dalam proses produksi tayangan samasama bermain dalam konstelasi yang dinamis; tidak semata-mata pantulan dari tindakan aktor dominan. Secara analitis, proses dinamis itu dapat mudah dilihat dengan memperlakukan praktik-praktik produksi tayangan sebagai "ranah" (field) tersendiri. Ranah tersebut merupakan suatu domain praktik tertentu yang memiliki logika atau pola permainannya sendiri; pola yang dibentuk berdasarkan kombinasi unik dari berbagai kapital yang melekat pada aktor-aktor yang terlibat (Postill 2010: 8).

Praktik-praktik dalam produksi tayangan televisi memiliki logika tersendiri yan spesifik, yang jelas berbeda dari pola praktik sehari-hari. Praktik-praktik tersebut membentuk jalinan sosial dan material yang mengarah pada hasil tertentu. Setiap tahap dalam proses produksi tayangan Mamah dan Aa Beraksi, sebagaimana diuraikan dalam bab-bab sebelumnya, memperlihatkan dinamika tindakan dan tingkat kekuatan aktor yang berbeda-beda dalam membentuk hasil yang dituju pada tiap tahap tersebut. Setiap aktor pun memiliki daya dan kekuatan yang berbeda di setiap tahapnya. Bisa jadi, di tahap tertentu, seseorang memiliki peran dan kekuatan yang begitu dominan, namun di tahap lain justru nyaris tak terlibat dalam permainan.

\section{Logika Kebudayaan dalam Produksi Kebudayaan di Media}

\subsection{Konvensi Lentur}

Beermuka dari kajian Amirudin (2016), jika dicermati proses-proses yang terjadi pada tahap penentuan tema untuk tayangan agama, terlihat bahwa setiap aktor memiliki posisi yang nyaris setara. Produser eksekutif, sebagai aktor yang secara formal berada pada piramida tertinggi dalam proses produksi, tak selalu mendominasi dalam memunculkan dan menetapkan tema. Ia bahkan bisa terseret oleh celetukan remeh dari anggota tim produksi di tangga hierarki paling bawah. Obrolan kecil sesaat ketika berada di ruang merokok dapat berakhir pada pilihan tema utama esok hari. Sebaliknya, sengotot apapun produser dalam mengusulkan tema belum tentu berujung pada tema yang bakal ditayangkan kemudian.

Mengapa hal itu mungkin terjadi ? Jika dilihat interaksi sehari-hari dalam proses produksi tanpa menyelami asumsi-asumsi di balik keputusan masing-masing aktor, tampaknya memang tidak ada penentu yang pasti sebagai patokan untuk mencandra kekuatan utama yang mendorong lahirnya suatu tema dalam tayangan. Akan tetapi, dari penyelaman etnografis dapat ditemukan unsur-unsur yang membangun pembentukan tema. Dapat dicatat setidaknya dua hal. Pertama, ada asumsi yang secara implisit disepakati bersama bahwa setiap tema harus mampu dikaitkan dengan pengalaman keagamaan orang awam. Pada titik ini, kriteria agama dalam norma-norma tekstualnya kurang menentukan dibanding dengan kriteria pengalaman nyata-atau setidaknya dipandang nyata oleh aktor-aktor di dalam proses produksi-yang berkemungkinan besar muncul di tengah masyarakat. Sementara, pengalaman religius dapat dialami oleh siapa pun, terlepas dari posisi hierarkisnya dalam tim produksi. Bahkan, seorang sopir atau office boy pun bisa memunculkan tema atas dasar pengalaman mereka-yang tentu kemudian dibawa oleh salah satu dari anggota tim ke dalam rapat.

Kedua, ada pula asumsi yang juga disepakati bersama bahwa tema harus mencerminkan tren di masyarakat. Kriteria ini juga sama licinnya dengan kriteria 
pengalaman keagamaan di atas, sehingga setiap aktor atau anggota tim dapat memunculkan, mengarahkan dan menegaskan tema apa yang paling pantas ditayangkan. Yang disebut tren itu bisa apa saja, mulai dari perbincangan tingkat rukun tetangga mengenai ucapan kasar seorang suami terhadap istrinya; perebutan harta waris; fenomena alam seperti gempa bumi atau gunung meletus; pemilihan umum; dan seterusnya. Tren tersebut mencakup hampir apa pun yang menjadi perbincangan media saat itu maupun perbincangan sehari-hari di lingkungan audiensi berada. Tren tersebut kemudian dijadikan cantolan peristwa bagi pembahasan ajaran-ajaran agama yang ditampilkan dalam tayangan Mamah dan Aa Beraksi.

Karena sifatnya yang umum dan lentur, dua asumsi di atas membawa konsekuensi pada cairnya interaksi para aktor dalam menentukan hasil tayangan. Dengan kalimat lain, dua "konvensi" di atas tidak dapat dikendalikan sepenuhnya oleh otoritas pengetahuan agama, yang mewujud dalam sosok Mamah Dedeh dan timnya, sekaligus juga tidak dapat sepenuhnya disetir oleh otoritas pasar-yang diwakili oleh manajemen perusahaan. Baik otoritas pengetahuan agama maupun otoritas pasar harus tunduk terhadap apa yang disebut "pengalaman nyata" dan "tren masyarakat". Pengalaman dan tren dapat muncul dari mana pun, sehingga memberi celah dan ruang bagi seluruh aktor yang terlibat dalam proses produksi untuk berpartisipasi secara aktif dan dinamis dalam pembentukan hasil tayangan.

\subsection{Interpenetrasi Agama dan Pasar}

Ronald Lukens-Bull (2008: 220) memberikan pengamatan menarik terhadap gejala kehadiran agama di era globalisasi. Menurutnya, produksi, konsumsi dan kontestasi gambar bukan sekadar produk globalisasi, tetapi juga merupakan tanggapan terhadap globalisasi tersebut. Pada titik ini, proses komodifikasi dan ideologisasi melalui gambar bertemu dan saling membentuk. Kapitalisme akhir, menurut LukensBull, "can involve both the ideologization of commodities and the commoditization of ideologies". Agama, sebagai salah satu wujud dari ideologi, tampil sebagai daya yang membentuk komoditas, tidak sekadar objek pasif yang dibentuk oleh proses komodifikasi segala lini kehidupan yang menjadi ciri globalisasi pasar. Dengan kata lain, yang terjadi bukan sekadar "komodifikasi religi", tetapi juga "religiusisasi komoditas".

Pencermatan dari dekat terhadap tayangan religi seperti Mamah dan Aa Beraksi memperlihatkan secara lebih jelas bagaimana proses komodifikasi dan religiusisasi tersebut bertemu. Kriteria komoditas pasar dan kriteria agama saling membentuk, sehingga akan sulit untuk menyimpulkan bahwa agama sedang mendominasi arena publik yang disebut pasar, atau sebaliknya agama telah ditaklukkan pasar-reduksireduksi yang banyak muncul di berbagai analisis populer. Kenyataan di ranah produksi tak sesederhana itu. Aktor 'religiusisasi' dan aktor 'komodifikasi' berproses secara interaktif, memengaruhi satu sama lain, dan di banyak kesempatan dapat mem-veto satu sama lain.

Memang benar, sebagai produk yang dilempar ke pasar, tayangan religi seperti Mamah dan Aa Beraksi tak luput dari hukum komoditas yang memiliki standar-standar tertentu. Visualitas tayangan sudah sangat jelas memperlihatkan itu. Penceramah harus tampil dengan tampilan visual tertentu, misalnya pakaian harus selaras dengan keseluruhan setting. Penceramah juga harus bersedia di-touch up. Hal-hal tersebut mungkin tidak dilakukan sebagai kebiasaan Mamah Dedeh dalam kehidupan di luar 
proses produksi. Demikian pula dengan penonton yang terlibat dalam proses produksi. Mereka mau tidak mau harus berseragam dengan warna pakaian dan pola jilbab yang selaras. Yel-yel dan gerakan khusus penonton live juga ditentukan agar kemasan tayangan sesuai selera pasar.

Namun demikian, di sisi lain, tampilan-tampilan visual tersebut dipandang hanya sebagai "alat" bagi Mamah Dedeh dan timnya untuk mendakwahkan religi kepada masyarakat luas. "Standar pasar" yang diterapkan dalam tampilan visual tidak dilihat sebagai wujud "penaklukan" agama, lantaran di sana juga berjalan kriteria agama, seperti terwujud dalam kostum yang harus memenuhi standar "pakaian muslimah". Pada titik ini, kriteria agama dapat dianggap memenangkan pertarungan ketika mampu membuat arena komersial mengadopsi aturan religi dalam berpakaian. Baik penceramah maupun kaum ibu yang menjadi penonton live mengenakan pakaian sesuai kriteria agama sebagaimana yang mereka gunakan pada pengajian di masjidmasjid. Di sini hanya ada perbedaan warna dan keseragaman. Ini boleh disebut sebagai wujud interpenetrasi yang simetris: agama melakukan penetrasi kepada pasar dengan cara membolehkan pasar pun melakukan penetrasi terhadap agama.

Contoh lain yang menarik adalah terkait pertanyaan yang berasal dari email. Dari penyelaman etnografis, kita tahu bahwa tidak seluruh pertanyaan benar-benar berasal dari pemirsa nyata. Tim produksi terkadang perlu membuat "improvisasi" dengan cara membuat email "palsu" yang berisi pertanyaan kepada Mamah Dedeh. Alasannya, tidak ada pertanyaan yang berasal dari email, atau ada tetapi kurang cocok dengan tema pembahasan. Dari segi kriteria pasar, pertanyaan dari email ini diperlukan untuk menciptakan kesan interaktif dan kekinian. Namun dari segi kriteria agama, praktik tersebut dapat dianggap melanggar nilai kejujuran atau pada titik tertentu dapat dinilai sebagai wujud penipuan. Namun, agaknya tim Mamah Dedeh, sebagai penjaga standar agama dalam tayangan, tidak terlalu mempedulikan. Sekali lagi, tampaknya "email palsu" tersebut diletakkan sebagai sarana agar dapat muncul jawaban-jawaban terhadap persoalan agama yang dibahas. Artinya, penetrasi pasar terhadap agama tidak menjadi masalah serius sejauh dipandang sebagai alat untuk menyampaikan dakwah agama.

Lebih lanjut, kriteria agama maupun pasar tak mampu sepenuhnya mengendalikan keseluruhan praktik yang muncul dalam arena produksi. Banyak tindakan kecil dan ekspresi yang berada di luar koridor agama maupun pasar. Contoh yang paling menonjol adalah tawa Mamah Dedeh. Dari segi orientasi pasar, sulit untuk menyebut gaya tawa Mamah Dedeh dibentuk oleh etiket komersil, bahkan pada titik tertentu dapat dibilang menyeleweng dari hukum komersial-tidak elegan dan terkesan urakan. Dari segi agama pun demikian. Anjuran agama konvensional mengasumsikan perempuan haruslah mampu mengendalikan cara bicara, apalagi cara tertawa-belum lagi yang melakukan adalah seorang ustadzah seperti Mamah Dedeh yang diasumsikan harus mencerminkan keteladanan. Namun, konvensi agama tersebut juga tampak tidak terlalu dipedulikan.

Dengan demikian, komodifikasi dan religiusisasi tidak secara total menjangkau keseluruhan praktik di dalam arena produksi. Bagi Bourdieu (1990), setiap ranah mengimplikasikan adanya habitus yang berbeda. Namun, tidak seluruh aktor memiliki trajektori yang sama dalam mengakumulasi cultural capital ketika masuk maupun ke luar dari ranah tertentu. Artinya, di dalam suatu ranah, berkemungkinan muncul 
ekspresi-ekspresi dari para aktor di luar inti permainan. Tidak ada inkorporasi total, individu-individu tetap memiliki disposisi yang dibangun melalui sejarah sosialisasinya tersendiri di luar arena produksi. Wajar jika muncul ekspresi dan tindakan yang sesuai dengan struktur tindakan dalam ranah. Di sanalah, kontradiksi menjadi mungkin. Suatu ekspresi atau tindakan barangkali tidak sejalan dengan kriteria agama maupun kriteria pasar, namun tetap hadir mewarnai permainan. Lebih dari itu, merujuk pada Turner (1986) yang akan dibahas di bagian berikut, jika keseluruhan praktik para aktor di dalam suatu ranah dipandang sebagai permainan maka permainan itu sesungguhnya merupakan wujud "pertunjukan budaya" (cultural performance) yang memungkinkan adanya pelenturan aturan, improvisasi, bahkan kontradiksi.

\subsection{Satu Permainan Banyak Hadiah}

Pertanyaannya kemudian, jika praktik dan interaksi yang dijalani para aktor dalam ranah produksi tersebut begitu kompleks dan multiarah, lantas apa sebenarnya jangkar yang memadukan semuanya. Mengapa para aktor tersebut merelakan diri untuk bersentuhan satu sama lain di arena yang dibatasi kriteria-kriteria eksplisit maupun implisit tertentu. Jika agama dan pasar, meski berperan besar, tidak mendominasi permainan-sehingga tidak dapat disebut sebagai jangkar pengikat, adakah bentukbentuk jangkar lainnya?

Untuk menjawab pertanyaan tersebut, kajian ini memanfaatkan konsep ranah dan pendekatan prosesual terhadap dinamika aktor-aktor di dalam ranah tersebut. Dalam suatu ranah permainan, FG Bailey (1969) dalam karya yang sudah klasik Stratagems and Spoils mengidentifikasi adanya lima elemen utama. Pertama, adanya hadiah atau piala yang dikejar oleh seluruh aktor pemain. Kedua, adanya personil atau aktor yang bermain. Ketiga, adanya kepemimpinan, dalam pengertian ada aktor utama yang disertai oleh sejumlah pengikut. Keempat, adanya kompetisi, dalam arti konfrontasi dan kontestasi untuk memperebutkan hadiah atau piala tersebut. Kelima, adanya juri atau wasit yang menentukan aturan main dan memutuskan pemenangnya. Bagi Bailey, setiap arena politik (formal dan informal) dapat ditelaah dengan menggunakan kerangka "teori permainan" semacam itu.

Meskipun pada titik tertentu, kita bisa melihat para aktor di dalam ranah produksi tayangan Mamah dan Aa Beraksi sebagai pemain-pemain yang tengah memperebutkan suatu hadiah, banyak pertanyaan segera muncul, terutama berkaitan dengan asumsi bahwa aktor-aktor bertindak secara rasional dengan perhitungan costbenefit. Asumsi tersebut sudah tentu akan menyempitkan analisis pada perkara perhitungan ekonomi, yang kemudian akan mengecilkan peran audiensi dan aktor lain yang tidak sedang mempertaruhkan keuntungan ekonomis. Akan tetapi, ketika "hadiah" (prize) dimengerti tidak sekadar keuntungan material-ekonomis, kita akan mampu melihat bahwa aktor-aktor tersebut-dari tim produksi, tim riset, tim Mamah Dedeh, hingga audiensi-memang sedang mengejar tujuan yang membuat mereka tergerak untuk bermain di arena produksi tersebut.

Victor Turner dapat melengkapi “teori permainan” Bailey. Bagi Turner (1986), permainan tidak sekadar melibatkan kompetisi guna memperebutkan kejuaraan, akan tetapi juga merupakan sebuah "pertunjukan budaya". Aktor-aktor yang bermain bukan semata hendak mencari kemenangan, melainkan terkadang yang dituju adalah permainan itu sendiri, sebab dalam permainan tersebut dimungkinkan adanya ruang sosial untuk "mempermainkan" secara lentur aturan-aturan dan kekangan-kekangan 
budaya. Artinya, jika permainan "kejuaraan" memperebutkan piala kemenangan maka permainan "pertunjukan" bertujuan memperoleh kenikmatan dalam menjalankan permainan itu sendiri.

Praktik-praktik produksi tayangan "Mamah dan Aa Beraksi" memperlihatkan betapa dua bentuk permainan tersebut dapat muncul secara bersama-sama. Bagi tim produksi, "hadiah" yang dikejar tentu saja adalah rating, yang dalam dunia pertelevisian dapat dikonversi ke dalam angka finansial. Berbagai tindakan dan proses yang tim produksi jalani, sebagaimana dipaparkan pada bab sebelumnya, dapat ditelusuri sebagai sebuah usaha memenangkan kualitas produk tayangan dengan rating yang tinggi. Akan tetapi ketika dikejar lebih lanjut mengenai kualitas seperti apa yang dianggap memiliki rating tinggi, tim produksi maupun tim riset hanya bisa mendugaduga, hanya menyebutkan kemungkinan-kemungkinan campuran tema, waktu tayang, atau pun situasi masyarakat yang melatarbelakangi tayangan tertentu. Campuran yang tepat dianggap menghasilkan rating yang tinggi. Tetapi ketepatan campuran itu tidak pernah dapat ditangkap dan dirumuskan secara utuh, dan ketika dicoba untuk dirumuskan senantiasa meleset_-senantiasa memunculkan kemungkinan lain, sehingga ketika rumusan tersebut diterapkan atau dijalankan ulang, tidak muncul hasil rating yang sama seperti diharapkan. Pada akhirnya, yang terjadi adalah memainkan campuran-campuran tersebut, melakukan permainan kreatif dalam menghubungkan tren, tema, visual dan elemen-elemen lainnya. Permainan kreatif ini cenderung menjadi tujuan yang lebih penting dikejar dibandingkan dengan rating yang licin dan sulit ditangkap itu.

Audiensi, yang tampak tidak sedang mengejar hadiah keuntungan ekonomis, sebenarnya juga sedang mengejar bentuk hadiah yang lain. Bertemu tatap muka secara langsung dengan Mamah Dedeh merupakan hadiah besar yang ingin diperoleh sebagian besar audiensi live. Bersalaman, berbicara langsung dan berfoto bersama, bagi penonton langsung, memiliki nilai yang jauh lebih tinggi dari sekadar nilai ekonomis. Dari penelusuran etnografis, dapat diketahui bagaimana mereka berjuang untuk memperoleh hadiah tersebut. Mereka mengeluarkan uang yang tidak sedikit, menunggu dalam waktu lama, mengikuti antrian yang panjang hingga berbulan-bulan, untuk dapat bertemu langsung dengan penceramah pujaan.

Tampil di tayangan televisi dalam acara live juga menjadi hadiah lain yang pantas dikejar. Sebagian besar penonton langsung adalah kaum ibu yang berasal dari kelompok pengajian. Muncul di layar televisi dan disiarkan secara luas merupakan kemewahan yang amat bernilai. Di kehidupan sehari-hari, barangkali mereka merupakan penonton-penonton televisi yang aktif mengikuti tayangan demi tayangan. Harapan menjadi aktor yang ditonton-bukan lagi yang menonton-terus terpupuk melalui proses menonton tersebut. Menjadi penonton di studio itu pada akhirnya menjadi impian yang nyata, mereka tidak hanya mampu menonton secara langsung Mamah Dedeh tetapi sekaligus juga ditonton banyak orang. Mereka memiliki posisi ganda: menjadi penonton sekaligus yang ditonton.

Pada titik tertentu, hadiah-hadiah nonmaterial tersebut dapat bertransformasi menjadi alat tukar (currency) baru. Hadiah tersebut dapat dipertukarkan dengan bentukbentuk nilai yang lain. Sebagai contoh, seorang politisi menggunakan hadiah tersebut sebagai alat tukar bagi suara dalam pemilihan umum. Sudah jamak bahwa politisi menggunakan uang sebagai sarana untuk "membeli" suara calon pemilih dalam pemilu. 
Namun, banyak juga politisi yang memakai cara berbeda untuk mengumpulkan suara. Tampil di televisi merupakan sarana baru. Seorang politisi di kawasan Depok Jawa Barat, misalnya, mengumpulkan kaum ibu dan menjanjikan mereka dapat tampil di acara Mamah dan Aa Beraksi. Sebagai gantinya, kaum ibu tersebut harus mencoblos sang politisi sebagai anggota Dewan Perwakilan Rakyat (DPR) di hari pemilihan nantinya. Tentu saja kaum ibu antusias untuk mengikuti "program" sang politisi, meskipun tidak ada jaminan bahwa mereka nantinya mencoblos sang politisi. Fenomena kecil ini menunjukkan bagaimana hadiah nonmaterial dapat menjadi alat tukar yang bisa dikonversi menjadi bentuk-bentuk kapital lain (Bourdieu, 1993).

Kembali ke pertanyaan di awal bagian ini, jangkar yang mengikat berbagai interaksi di dalam proses produksi ternyata tidaklah tunggal. Turner, di satu sisi, menyatakan bahwa ranah permainan itu berisi aktor-aktor yang saling bersaing memperebutkan hadiah yang sama (Turner 1974). Namun di sisi lain, Turner juga mengakui bahwa dalam permainan tidak semua aktor mengejar hadiah, tetapi lebih mengejar keasyikan bermain itu sendiri (Turner 1986). Melalui kajian ini, kita dapat mengatakan satu hal lagi bahwa memang ada hadiah yang dikejar oleh aktor-aktor yang bermain, namun bentuk hadiah tersebut tidaklah tunggal. Setiap aktor memiliki hadiahnya sendiri, yang bagi aktor lainnya belum tentu penting nilainya. Aneka ragam hadiah itu semua terjalin rapi dalam satu ranah yang menjadi wadah tindakan dan interaksi para aktor. Itulah yang membuat seluruh aktor dapat bermain bersama secara padu.

\section{Diskusi: Produksi Budaya Panggung Media}

Turner menyediakan kerangka pemahaman yang relevan dalam melihat dinamika produksi dan reproduksi budaya. Dalam etnografi dan analisisnya terhadap komunitas ritual di Afrika, Turner memaparkan bagaimana drama-drama sosial dan panggungpanggung ritual merupakan bagian integral dari produksi budaya komunitas tersebut. Pararel dengan yang dinyatakan Turner tetapi berbeda konteks sosialnya, peneliti ingin mengatakan bahwa di era serbamedia, dinamika produksi budaya telah diwarnai secara signifikan oleh panggung-panggung media. Praktik-praktik sosial di dalam proses produksi tayangan Mamah Dedeh menunjukkan, acara tersebut tidak hanya menjadi panggung tersendiri yang terpisah dari kehidupan sehari-hari. Tema-tema yang dibahas dan dibincangkan oleh Mamah Dedeh muncul dari kenyataan hidup paling nyata di keseharian para audiensi. Pada saat yang sama, ujaran-ujaran Mamah Dedeh juga mewarnai kehidupan sehari-hari audiensi. Panggung media dan panggung hidup seharihari di sini tak terpisahkan. Praktik hidup sehari-hari sudah menjadi bagian dari tenunan media, pun sebaliknya, praktik media telah menjadi bagian dari hidup sehari-hari (Mazzarella 2004; Abu-Lughod 1997; Abu-Lughod, Ginsburg, dan Larkin 2002).

Pernyataan di atas tak berarti panggung-panggung ritual absen dalam proses produksi dan reproduksi budaya. Tidaklah benar untuk melakukan penyederhanaan bahwa di era posmodern panggung ritual sudah diganti oleh panggung media. Potret etnografis dari ruang studio Mamah Dedeh menunjukkan panggung ritual dan panggung media terajut secara tumpang tindih. Jika dicermati, ceramah Mamah Dedeh-yang di dalamnya memuat banyak ritual doa-doa dalam Islam - tak sepenuhnya bentukan media. Sebelum muncul di media, baik radio maupun televisi, Mamah Dedeh menjalani ceramah di tengah-tengah kolektifitas sosial secara langsung, tanpa melalui perantara media. Mamah Dedeh melaksanakan ritual dakwah itu dari jamaah ke jamaah lainnya. 
Kini, ketika Mamah Dedeh secara rutin tampil di televisi, ia tetap juga melakukan ceramah secara langsung di tengah-tengah masyarakat. Jika kita bisa menyebut ceramah sebagai ibadah, yang merupakan ritual religius, kita dapat mengatakan bahwa media sebagai panggung produksi budaya tak serta merta menggantikan jamaah nyata sebagai panggung sosial. Bahkan, walaupun panggung sosial itu diformat ulang dalam sebuah acara live di layar televisi, hal itu tidak juga menggantikan panggung sosial yang sesungguhnya. Proses produksi dan reproduksi budaya berlangsung melalui layar televisi, melalui kehidupan sosial sehari-hari dan melalui interaksi antara keduanya.

Di mana peran relasi global-lokal dalam konteks ini ? Mazzarella (2004) mengatakan bahwa di era budaya yang termediasi ini batas-batas lokalitas nyaris tak dapat lagi dipertahankan, sebab budaya dibentuk melalui keterhubungan media yang berlangsung secara global. Di sini Mazzarella berlebihan. Potret etnografi di ruang produksi tayangan Mamah Dedeh memperlihatkan globalitas hanya dapat tampil dalam wujud lokalitas. Sebutlah bahwa format tayangan show yang menampilkan adanya satu narasumber yang berinteraksi dengan penonton di studio dan di rumah, dengan dipandu oleh seorang pembawa acara, merupakan format umum yang dikenal di seluruh dunia. Akan tetapi, seperti kita lihat, format tersebut hanya dapat ditangkap dalam imajinasi tentang "suasana pengajian ibu-ibu" yang sudah muncul dalam realitas sosial seharihari di tingkat lokal. Bentuk ekspresi ceramah tak lepas dari "lokalitas", dari pilihan pakaian, setting ruangan, pola interaksi, cara tutur, sikap penceramah dan reaksi audiensi di studio, hingga bentuk humornya. Begitu pula, apa-apa yang dibicarakan, yang dibahas, yang menjadi pertanyaan dan concern adalah bagian dari produk "lokalitas".

Akan tetapi, tesis Mazzarella juga memiliki relevansi yang tinggi. Tak dapat dibantah memang bahwa media telah mengubah wujud panggung sosial Mamah Dedeh. Panggung sosial itu kini memiliki rentang geografis, sosial dan waktu yang melampaui panggung-panggung "konvensional", yang terikat ruang dan waktu. Jika Mamah Dedeh berceramah di hadapan jamaah di suatu kampung, jamaah hanya terbatas pada mereka yang hadir di lokasi dan waktu tersebut. Sementara itu, dalam tayangan televisi, syuting hari ini bisa ditonton besok dan diulang kapan saja. Rentang audiensi tak terbatas pada ruang konkrit. Jamaah Mamah Dedeh meluas pada siapa pun yang dapat dijangkau layar televisi. Di sini, konsep budaya harus dimengerti secara berbeda, tidak hanya merupakan skema makna yang stabil dan konstan, namun menjadi "something whose elements are produced, censored, paid for, and broadcast across a nation, even across national boundaries" (Abu-Lughod 1997: 121). Dengan demikian, sekali lagi, budaya menjadi kerangka yang elemen-elemennya terus diproduksi dan diproduksi kembali melalui proses di studio, proses sehari-hari dan proses interaktif antar keduanya.

\section{Simpulan}

Bertumpu pada studi produksi tayangan dari Amirudin (2016), sebagai suatu studi yang menggunakan perspektif antropologi anti-esensialis, memperlihatkan bahwa:

Pertama, ruang produksi tayangan merupakan "ranah produksi budaya" yang bukan saja cerminan dari ruang produksi budaya di luarnya tetapi merupakan ranah yang relatif otonom yang memiliki logika dan pola permainannya sendiri. Kekuatan dominan yang menguasai media tidak serta merta tampil sebagai aktor dominan dalam proses produksi tayangan tetapi tampak diversitas aktor yang terjalin dalam proses produksi tayangan sebagai wujud mikro dari proses produksi kebudayaan sama-sama 
bermain dalam konstelasi yang dinamis, tidak sekadar disetir oleh kehendak mengakumulasi modal dan bukan merupakan pantulan dari tindakan aktor dominan dalam membentuk hasil yang dituju.

Kedua, dalam ranah produksi tayangan terlihat bagaimana logika dan pola permainan berlaku dalam ranah produksi budaya, yakni: (1) aktor produser eksekutif yang memiliki posisi hirarki yang lebih tinggi tidak selalu mendominasi penentuan tema. Penyusunan tema terjadi melaluikonvensi lentur antara pengalaman nyata keagamaan orang awam dan tren di masyarakat yang tidak sepenuhnya dapat dikendalikan oleh otoritas pengetahuan agama Mamah Dedeh dan otoritas pasar yang diwakili tim produksi. (2) Kriteria agama dalam proses produksi tayangan dapat melakukan penetrasi pada kriteria pasar dengan cara membolehkan pasar melakukan penetrasi pada agama. Ada interpenetrasi simetris antara agama dan pasar dalam proses produksi tayangan. (3) Agama dan pasar meski berperan besar dalam produksi tayangan, tetapi tidak serta merta mendominasi permainan. Dia bukan satu-satunya jangkar pengikat dan ada jangkar pengikat lain yakni hadiah yang dikejar dan keasikkan bermain dalam permainan itu sendiri. Jangkar pengikat yang menjahit interaksi tidaklah tunggal.

Ketiga, dalam ruang produksi tayangan, produksi kebudayaan diwarnai oleh panggung media yang tidak terpisahkan dari panggung sosial kehidupan sehari-hari. Melalui persepsi terhadap imaji yang dibawa para aktor, panggung ritual dan panggung media terajut secara tumpang tindih. Hal ini berarti, di era serbamedia, dinamika produksi budaya telah diwarnai secara signifikan oleh panggung-panggung media, namun praktik-praktik sosial di dalam proses produksi tayangan Mamah Dedeh menunjukkan, panggung media tidak terpisah dari kehidupan sehari-hari. Praktik hidup sehari-hari sudah menjadi bagian dari tenunan media, pun sebaliknya, praktik media telah menjadi bagian dari hidup sehari-hari. Temuan ini sekaligus menegaskan pemikiran Mazzarella (2004) tentang mediated culture sebagai konsep kunci untuk melihat kebudayaan dalam kerangka globalisasi. Globalisasi menyebabkan perubahan terhadap konsep kebudayaan yang pada awalnya memiliki batasan jelas menjadi sesuatu yang kompleks. Proses-proses yang terjadi dalam kerja media yang melibatkan aktoraktor adalah sebagai bagian dari pembentuk kebudayaan itu sendiri. Hal itu terjadi mengingat media memiliki fungsi mirroring yang mampu memediasi kebudayaan dari yang ada dalam panggung sosial, panggung media, dan sekaligus proses interaksi di antara keduanya.

Dari segi teoritis, kajian Amirudin (2016) mengandung sejumlah pembelajaran yang dapat diambil sebagai wujud kontribusi disiplin antropologi di Indonesia. Pertama, kajiannya menunjukkan bahwa teori ranah produksi budaya yang dicetuskan oleh Bourdieu (1993) dan Turner (1974) dapat secara produktif dimanfaatkan untuk meneropong gejala media yang semakin menjadi ciri era informasi global. Tentu saja sejumlah penyesuaian diperlukan agar suatu teori lebih dekat dengan konteks persoalan yang diteliti. Dalam penelitian ini, yang menjadi fokus adalah proses produksi suatu tayangan televisi; bagaimana aktor-aktor memainkan peran, otoritas, imajinasi dan kapasitas teknisnya untuk membentuk satu produk tayangan.

Dalam pemikiran Turner (1974), ranah merupakan seperangkat paradigma yang memuat aturan-aturan yang diterapkan dalam satu ruang konkrit (arena) pertarungan 
kekuasaan di suatu masyarakat. Unit analisis Turner adalah masyarakat. Ranah ala Turner berada dalam konteks holistik suatu masyarakat. Penelitian ini tentu tidak berpretensi menganalisis secara holistik suatu masyarakat, namun hanya berfokus pada praktik bermedia. Hal utama yang diadopsi dari Turner dalam penelitian ini adalah, pertama, paradigma prosesual dan, kedua, logika permainan dalam suatu ranah.

Paradigma prosesual mengimplikasikan ditangguhkannya asumsi-asumsi politik-ekonomi yang memperlakukan kekuasaan (ekonomi maupun politik) sesuatu yang pasti menentukan arah tindakan dan hasilnya. Paradigma prosesual lebih melihat bagaimana secara konkrit aktor-aktor bermain dan memainkan berbagai kekuatan, imajinasi, otoritas dan keterampilan praktis mereka. Logika permainan Turner memungkinkan peneliti melihat pola tindakan para aktor dalam mengejar hadiah atau piala (prize) dan bagaimana pada kesempatan lain para aktor memperlakukan permainan sebagai pertunjukan (performance) yang tidak berwatak kompetitif. Pada titik ini, peneliti mengembangkan lebih jauh bahwa tindakan yang berwatak kompetitif mungkin terjadi namun hadiah yang dikejar dalam suatu permainan tidak harus tunggal.

Sementara itu, ranah dalam perspektif Bourdieu tampaknya lebih mengarah pada metafor pasar ketimbang metafor permainan sebagaimana versi Turner. Ranah, bagi Bourdieu, adalah ruang di mana para aktor mempertukarkan dan memperebutkan modal-modal yang ada. Sebagaimana Turner, Bourdieu juga memberikan kerangka yang memungkinkan peneliti untuk melihat dinamika relasi para aktor sehingga peneliti tidak terjebak pada determinisme "struktur" ekonomi atau politik. Di sisi lain, Bourdieu juga membantu peneliti melihat bahwa kekuatan (atau modal) yang menggerakkan tindakan bukan semata ekonomi atau politik, tetapi juga imajinasi, nilai agama dan pengakuan sosial.

Kedua, kajian Amirudin (2016) menyarankan perlu dikoreksinya asumsi-asumsi politik ekonomi dalam membaca relasi media dan budaya. Pola pemikiran yang banyak terinspirasi dari Adorno (1991) itu memandang media sebagai bagian dari industri budaya yang nyaris seluruh geraknya ditentukan oleh kelas dominan. Artinya, dalam alur pikir tersebut, produk media atau produk industri budaya diperlakukan tak lain hanya sebagai cerminan dari ideologi dominan yang sekaligus penguasa ekonomi dan politik dominan. Gerak budaya, ekonomi dan politik dianggap sejajar berdasarkan kategori kelas. Penelitian ini memperlihatkan pola berpikir yang berbeda, bahkan pada titik tertentu berlawanan. Dengan berfokus pada ranah produksi, penelitian ini membuktikan bagaimana kekuatan ekonomi dominan tak senantiasa mendominasi proses produksi tayangan. Aktor-aktor yang bahkan dianggap tidak memiliki posisi ekonomi dan politik signifikan pun ternyata memainkan peran penting dalam membentuk produk budaya.

Ini menjadi memungkinkan karena produk budaya berangkat dari imajinasi dan persepsi atas imajinasi. Produser dan tim kreatif berupaya "menangkap" imajinasi masyarakat, dan pada saat yang sama merupakan bagian dari masyarakat itu sendiri. Aktor-aktor lain juga demikian, turut memunculkan imajinasi dan terlibat "menangkap" imajinasi kelompok masyarakat yang lebih besar-yang terkadang didefinisikan sebagai "tren". Keseluruhan imajinasi itu berinteraksi sedemikian rupa secara dinamis dalam kerangka waktu dan ruang tertentu. Momen, atau ruang dan waktu, yang berbeda dapat menciptakan perbedaan dalam peran aktor dan produk budaya yang berbeda. Pada satu momen, aktor tertentu memainkan peran lebih dominan namun pada momen lain dia hanya sebagai pemeran pinggiran. Ini hanya dapat dilihat secara etnografis dari dekat dengan paradigma prosesual ketimbang dengan asumsi determinasi ekonomipolitik. 


\section{Daftar Pustaka}

Amirudin. 2016. Tayangan Religi sebagai Ranah Produksi Budaya: Kajian terhadap Tayangan Mamah dan Aa Beraksi di Stasiun TV Indosiar. Disertasi. Jakarta: Unibersitas Indonesia.

2011. Media dan Produksi Budaya. Sabda Jurnal Kajian Kebudayaan (ISSN 1410-7910). Semarang: FIB Undip. Vol 11, hal 18.

Abu-Lughod, Ginsburg, and Larkin B. 2002. Media Worlds: Anthropology on New Terrain. Berkeley: University of California Press.

Adorno, T.W. 1991.The Culture Industry: Selected Essays on Mass Culture, J. Bernstein (ed). London: Routledge.

Alam, Bachtiar. 1998. 'Globalisasi dan Perubahan Budaya: Perspektif Teori Kebudayaan’, dalam Jurnal Antropologi Indonesia 21 (54): 1-11.

Ang, Ien. 1985. Watching Dallas: Soap Opera and the Melodramatic Imagination. London: Methuen.

Ang, Ien. 1991. Desperately Seeking the Audience. London: Routledge.

Appadurai, Arjun. 1996. Modernity at Large: Cultural Dimensions of Globalization. Minneapolis, London: University of Minnesota Press.

Askew, Kelly. 2002. 'Introduction to Media Anthropolog', dalam Kelly Askew \& Ricahrd R Wilk (eds); The Anthropology of Media a Reader (Oxford: Blackwell Publishing). p.1-12.

Bailey, F.G. 1969. Stratagems and Spoils. Oxford: Blackweel.

Baudrillard, J. 1975. The Mirror of Production. Telos Press, St. Louis, MO.

Baudrillard, J. 1981. For a Critique of the Political Economy of the Sign. Telos Press, St. Louis, MO.

Bourdieu, Pierre. 1977. The Outline of a Theory of Practice, trans. R. Nice. Cambridge M.A.: Cambridge University Press.

Bourdieu, Pierre. 1992. Language and Symbolic Power. Cambridge: Polity Press.

Bourdieu, Pierre. 1993. The Field of Cultural Production: Eassys on Art and Literature. New York: Columbia University Press.

Bourdieu, Pierre. 1996. On Television. New York: The New Press.

Bourdieu, Pierre. 1998. Practical on the Theory Reason of Action. California, Stanford: Stanford University Press.

Bourdieu, Pierre. 2005. Distinction: a Social Critique of a Judgement of Taste. trans. R. Nice. Cambridge, M.A.: Cambridge University Press. 
Brauchler, B., dan Postill, J. 2010. 'Theorizing Media and Practice', dalam Anthropology of Media Vol. 4. New York: Berghahn Books.

Cantor, Muriel. 1972. The Hollywood TV Producer: His Work and His Audience. New York: Routledge.

Durkheim, E., 1976. The Elemementary Forms of The Religious Life. Terjemahan J.E. Swam: . London: Allen-Unwin.

Fiske, John and Hartley, John. 2003. Reading Television. London: Routledge.

Fiske, John. 1987. Television Culture: Popular Pleasures and Politics. London: Routledge.

Fisher, Michael M.J. 2007. 'Culture and Cultural Analysis as Experimental Systems', dalam Cultural Anthropology 22 (1): hal 1-65.

Giddens, Anthony, 1984. The Constitution of Society: Outline of the Theory of Structuration. Berkeley: University of California Press.

Gitlin,Todd. 1983. Inside Prime Time. New York: Pantheon.

Hall, Stuart., et. al. (eds). 1980. Culture Media Language. London: Routledge.

Jenkins, Richard. 1992. Key Sociologist Pierre Bourdieu. London: Routledge

Kitley, Philip. 2000. Konstruksi Budaya Bangsa di Layar Kaca. Jakarta: PT Media Lintas Inti Nusantara

Lukens-Bull, Ronald. 2008. "Commodification of Religion and The 'Religification' of Commodities: Youth Culture and Religious Identity", dalam Pattana Kitiarsa (ed): Religious Commodifications in Asia: Marketing Gods (New York: Routledge). p.220-234

Mayer, V., Banks. 2009. 'Introduction to Production Studies', dalam Bank V Mayer, Miranda J., Caldwell, dan John T (Eds) Production Studies: Cultural Studies of Media Industries (New York: Routledge). p1-5

Mazzarella, William. 2004. 'Culture Globalization, Mediation', dalam Annual Review of Anthropology. 33: 345-367.

McQuail, Denis. 1983. Mass Communication Theory: an Introduction. London: Sage Publication.

Newman, M.Z. dan Levine, E. 2011. Legitimating Television: Media Convergence and Cultural Status. New York: Routledge.

Novenanto, Anton., 2009. Mediated Disaster: The Role of Alternatif and Mainstream Media in the East Java Mud Vulcano Disaster. MA Thesis in Department of Cultural Anthropology and Development Sociology. Leiden: University of Leiden.

Ortner, Sherry B. (2009). 'Studying Sideways: Ethnographic Access in Hollywood,' dalam MayerV. Banks, M. CaldwellJ (Eds); Production Studies: Cultural Studies 
of Media Industries (New York: Routledge). p.78 - 92.

Peterson, Mark, A., 2009. 'Response to John Postill Social Anthropology/ Anthropologie Sociale', dalam European Association of Social Anthropologists. Vol 17, (3) p334-344.

Pink, Sarah, et al. 2004. Working Images: Visual Research and Representation in Ethnography. London And New York: Routledge

Postill, J. 2013. 'Fields as Dynamic Clusters of Practices, Games and Socialitie', dalam Amit (ed); Sociality: An Anthropological Interrogation (Oxford and New York: Berghahn). Diakses melalui http:/wwww. academia.edu/2046704/ Fields_as_dynamic_clusters_of_practicgames and_socialities pada 25 April $\underline{2013}$.

Rappaport, Roy A. 1999. Ritual and Religion in the Making of Humanity. Cambridge: Cambridge University. Sen, Krisna \& David T. Hill. 2001. Media, Budaya Dan Politik di Indonesia. Jakarta: PT Media Lintas Inti Nusantara

Shoemaker, Pamela J. dan Stephen D Reese. 1991. Mediating the Message: Theories of Influence on Mass Media Content. London: Longman.

Storey, John. (editor). 1994. Cultural Theory and Popular Culture A Reader. New York: Harvester Wheatseaf.

Storey, John. 2001. Cultural Theory and Popular Culture: An Introduction. London: Pearson Prentice Hall.

Storey, John. 2008. Cultural Studies dan Kajian Budaya: Pengantar Komprehensif Teori dan Metode. Terjemahan Layli Rahmawati (Yogyakarta: Jalasutra).

Turner, Victor W. 1969. The Ritual Process: Structure and Anti-Structure.New York: Cornell University Press.

Turner, Victor W. 1974. Dramas, Fields and Metaphors: Symbolic Action in Human Society. Ithaca, New York: Cornell University Press.

Turner, Victor W. 1987. The Anthropology of Performance. Preface: Richard Sechechner. New York: PAJ Publications.

Valdivia, Angharad., N. 2003. A Companion to Media Studies. Oxford: Blackwell.

Van Loon, Joost. 2008. Media Technology: Critical Perspectives. Glasgow: Open University Press.

Williams, Raymond. 2003 [1974]. Television: Technology and Cultural Forms. London: Routledge.

Zafirau, Stephen. 2009. 'Audience Knowledge and the Everyday Lives of Cultural Producers in Hollywood', dalam Mayer, Vicki, Banks, Miranda J., Caldwell, John T (eds); Production Studies: Cultural Studies of Media Industries (New York: Routledge).p 302-324 